\title{
Moderators of Candidate Name-Order Effects in Elections: An Experiment
}

\author{
Nuri Kim \\ Stanford University \\ Jon Krosnick \\ Stanford University \\ Daniel Casasanto \\ University of Chicago
}

\begin{abstract}
Past studies of elections have shown that candidates whose names were listed at the beginning of a list on a ballot often received more votes by virtue of their position. This article tests speculations about the cognitive mechanisms that might be responsible for producing the effect. In an experiment embedded in a large national Internet survey, participants read about the issue positions of two hypothetical candidates and voted for one of them in a simulated election in which candidate name order was varied. The expected effect of position appeared and was strongest (1) when participants had less information about the candidates on which to base their choices, (2) when participants felt more ambivalent about their choices, (3) among participants with more limited cognitive skills, and (4) among participants who devoted less effort to the candidate evaluation process. The name-order effect was greater among left-handed people when the candidate names were arrayed horizontally, but there was no difference between left-and right-handed people when the names were arrayed vertically. These results reinforce some broad theoretical accounts of the cognitive process that yield name-order effects in elections.
\end{abstract}

KEY WORDS: ballot name order, primacy effect, information, ambivalence, cognitive skill, cognitive effort

Psychologists have long been fascinated with order effects in social influence and choice. For example, since the early days of systematic research on persuasion, the order in which opposing messages are presented has been recognized to influence their impact on attitudes (e.g., Haugtvedt \& Wegener, 1994; Hovland, Campbell, \& Brock, 1957). The order of information can also be important in forming impressions of people (e.g., Anderson \& Hubert, 1963; Asch, 1946; Forgas, 2011; Jones \& Goethals, 1972; Webster, Richter, \& Kruglanski, 1996). When answering multiplechoice questions in questionnaires, people are influenced by the order in which the options are presented (e.g., Krosnick \& Alwin, 1987). When taste-testing foods or beverages, people are influenced by the order in which products are experienced (e.g., Dean, 1980; Mantonakis, Rodero, Lesschaeve, \& Hastie, 2009). Articles published more toward the front of an issue of a journal are cited more than ones that appear later (Berger, 2011). And in elections, the order of candidate names 
on ballots influence election outcomes (e.g., Miller \& Krosnick, 1998). This article focuses on order effects in this latter context.

Ballots offer a unique case of simultaneous option presentation (Mogilner, Shiv, \& Iyengar, 2013) that has been the focus of recent research. Elections are, of course, processes of communication in which collectivities of individuals express their preferences. The effectiveness of such communication hinges in part upon the fairness and transparency of the process. In principle, structural features of the electoral process should not award advantages or disadvantages to any of the candidates. That is, democracy requires a procedurally "level playing field" on which every candidate has equal access to victory. Yet much research done during the last 50 years has pointed to one aspect of ballots that do sometimes appear to cause bias in election outcomes: the order of candidates' names (for a review, see Krosnick, Miller, \& Tichy, 2004).

This article offers a theory of the psychology underlying name-order effects, which yields a list of potential moderators of the effect. Tests of the impact of these moderators afford the opportunity to test the logic of the generative theory. Unfortunately, real elections are limited in the degree to which they can be used to reveal the psychology of name-order effects, because it is impossible to measure many attributes of individual voters, and it is impossible to manipulate attributes of the candidates and of campaigns. So we carried out tests in a context that did allow for such measurements and manipulations: a simulated two-candidate election conducted within an Internet survey of a national sample of American adults. Some moderators that cannot be easily measured in real electoral settings were measured, and some posited moderators were manipulated across participants to allow for strong causal inference. We begin below by reviewing the existing literature on name-order effects and their moderators, outline the theory and predictions about moderators, and then describe the methods, findings, and implications of the experiment.

\section{Name-Order Effects in Elections}

The body of research on name-order effects indicates that candidates often received more votes when their names were listed first than when their names were listed after the names of one or more candidates with whom they competed. Although one recent study failed to find so-called "primacy effects" (Alvarez, Sinclair, \& Hasen, 2006), and another found them to occur only for candidates not affiliated with major political parties (Ho \& Imai, 2008), many other studies have found evidence suggesting that primacy effects often occur (e.g., Koppell \& Steen, 2004; Krosnick et al., 2004; Miller \& Krosnick, 1998).

For instance, Miller and Krosnick (1998) examined the 1992 general elections in the three largest counties in Ohio, where candidate name order was rotated from precinct to precinct. Statistically significant name-order effects appeared in $48 \%$ of the races. The advantage of being in first position was an average of $2.5 \%$. Even in races where the name-order effect was not statistically significant, $75 \%$ of the observed vote-share differences were in the direction of primacy effects, a result very unlikely to have occurred by chance alone and suggesting that primacy effects were pervasive. ${ }^{1}$

More recently, Koppell and Steen (2004) found that among 180 candidates running in the 1998 Democratic primary elections in New York City, 161 received more votes when listed first. The average first-position advantage was about 3.4 percentage points, and the largest boost was 14.5 points. Krosnick and colleagues (2004) also found that in the race for President of the United States

\footnotetext{
${ }^{1}$ Past studies of name-order effects have often entailed design limitations that compromise the clarity of their empirical demonstrations (for a review, see Miller \& Krosnick, 1998). One common design drawback was a lack of random assignment to different name orders, which made it impossible to disentangle order effects from other conflated factors. Another factor limiting some past studies was improper statistical significance testing, which prevented researchers from distinguishing reality from illusion.
} 
in 2000, 19 of 21 tests (for seven candidate pairs running in California, North Dakota, and Ohio) manifested a trend in the direction of primacy, nine of which were statistically significant. Ho and Imai (2006) found name-order effects for some candidates running in the 2003 California gubernatorial recall election. And Ho and Imai (2008) found name-order effects in primaries and in statewide general elections in California held between 1978 and 2002.

\section{Moderators of Name-Order Effects}

If primacy effects are indeed real, why do they occur? Why would any citizen go to the trouble of going to the polls and then cast a vote that is influenced by something so trivial as the order of the names on the ballot? And when are name-order effects most likely to occur?

Some past studies have explored the conditions under which primacy effects are most likely to appear and the characteristics of voters who are most likely to manifest these effects (e.g., Koppell \& Steen, 2004; Miller \& Krosnick, 1998). But these studies have been limited in their ability to do so, because they studied voting behavior of individuals aggregated into precincts or districts and did not collect information about the characteristics of individual voters. Furthermore, some proposed moderators, such as the amount of information that the news media disseminated to voters about the candidates, were studied observationally, limiting the strength of causal inferences that could be made.

\section{Why Name-Order Effect Might Occur}

One possible explanation for primacy effects involves the tremendous burden levied on voters in the context of American democracy. Being a "good citizen" requires considerable time and effort, much like the responsibilities of a part-time job. On most ballots, numerous candidates vie for a voter's support, and the issues at stake in any campaign are often complex. This means that developing solid knowledge with which to choose between candidates is challenging. Some races receive so little media attention that even very effortful voters have trouble detailing the job responsibilities involved and the credentials, track records, and philosophies of the competing candidates.

As a result, people may sometimes vote for candidates and on referenda with relatively little relevant information. If a voter walks into a voting booth with a clear preference for a candidate in a highly visible race, possesses little to no information about races further down on the ballot, and feels obligated to vote in those latter races in order for his or her ballots to be counted, voters may choose a candidate in each such race arbitrarily. Such arbitrary choices may be biased toward selecting the first name listed. Thus, name-order effects may be most likely when voters are uninformed about the candidates running in a particular race. We refer to this as the "information deficit" hypothesis.

However, name-order effects might also sometimes occur under very different conditions: when voters are very well informed. Consider a voter who has devoted great effort to learning about candidates competing for President of the United States and has discovered an array of reasons to vote for and against each one. When he or she finally walks into the voting booth, making a choice between the candidates might be very difficult, because the pros and cons of the candidates nearly balance out. As a result, when under pressure to make a choice and move on with life, the voter again might choose arbitrarily, and in such situations, a bias toward the first-listed name might occur. ${ }^{2}$ Thus, name-order effects might occur due to ambivalence. We refer to this as the "ambivalence" hypothesis.

\footnotetext{
${ }^{2}$ Ambivalence towards candidates is not uncommon. For example, one study suggested that about $30 \%$ of the electorate hold ambivalent attitudes toward the major American political parties (Basinger \& Lavine, 2005). As would be expected, more ambivalent citizens take longer to crystalize their preferences (Lavine, 2001).
} 


\section{Factors that Precipitate Name-Order Effects}

The information deficit and ambivalence hypotheses suggest a series of possible moderators of the name-order effect.

Information volume. In light of the information deficit hypothesis, name-order effects might be especially likely to occur when voters know little about the candidates competing in a race. Consistent with this logic, Miller and Krosnick (1998) found that primacy effects were smaller in races that had been covered more frequently in the news. Volume of media attention to a race seems most likely to be positively correlated with the amount of knowledge that voters gain about the candidates. But the observational nature of such analysis precludes drawing the strongest causal conclusions about the effects of knowledge volume, so this hypothesis merits further study.

Ambivalence. No past research has yet explored whether name-order effects are especially likely to occur among voters who feel deeply ambivalent about the candidates, seeing pros and cons to both and unable to comfortably choose between them. However, previously reported evidence that primacy effects have occurred in the race for President of the United States (a superpublicized contest) seems unattributable to lack of information. This leaves open the possibility that ambivalence might incline some voters to grab the first name they see.

Cognitive skills. In light of the information deficit hypothesis, another potential moderator of name-order effects might be a voter's level of cognitive skills. The term "cognitive skills" refers to the ensemble of abilities that enable interpreting incoming information, storing it in memory, retrieving the information later, and integrating the retrieved information in order to select between candidates. Voters who have strong cognitive skills are likely to accumulate relatively large stores of information about candidates, whereas people with more limited cognitive skills may be exposed to information about candidates but may be less able to encode it, to retain it, and to use it to form thoughtful judgments. Therefore, these individuals may be less equipped to vote on substantive bases, so they may be more susceptible to influence by name order.

Cognitive effort. Even if a person is able to perform the cognitive tasks involved in encoding, storing, retrieving, and integrating information about candidates to choose between them, the individual may not be motivated to do this cognitive work. If that is the case, even after exposure to an array of information, a person may end up relatively uninformed about the candidates. A state of low information might exacerbate the likelihood of manifesting name-order effects. Some voters may exert effort when encountering information about candidates because they have a general tendency to process all information carefully (e.g., Cacioppo \& Petty, 1982). Other voters may exert effort because they care about politics in particular and enjoy thinking carefully about that topic (e.g., Glenn \& Grimes, 1968). Whatever the cause, expending more cognitive effort to learn and think about candidates may attenuate name-order effects.

Name-array orientation. Another possible moderator is the layout of candidates' names on the ballot. Some ballots present candidate names in a horizontal array, with names next to one another. Other ballots present candidate names in a vertical array, with some names above others. And still other ballots present names in grids involving both vertical and horizontal arrays of names. No prior study has examined whether horizontal versus vertical presentation of candidate names affects voters' choices. Some scholars in educational testing (e.g., Haladyna, Downing, \& Rodriguez, 2002) and questionnaire design (e.g., Dillman, Smyth, \& Christian, 2009) have recommended presenting response choices vertically rather than horizontally. In line with this recommendation, we explored whether the name-order effect would be weaker when names were presented vertically than when presented horizontally.

Handedness. Primacy effects have generally been assumed to result from the temporal order in which voters encounter the names on a ballot as they read from top to bottom or left to right. Could 
ballot-order effects arise from the spatial positions of names on a ballot, as well as (or instead of) their temporal order?

The spatial positions of items on a page or a computer screen can influence a wide variety of judgments and behaviors. Numerous studies suggest that people implicitly associate "up" with "good" and "down" with "bad" (e.g., Casasanto, 2009; Meier \& Robinson, 2004; Stepper \& Strack, 1993; Tourangeau, Couper, \& Conrad, 2013). These associations are present in linguistic idioms and metaphors (e.g., "high on life"; "down in the dumps") and are embodied in physical movements as well (e.g., standing tall when feeling proud and slouching when feeling sad). When voters demonstrate what appears to be a preference for the first candidate in a list of names, could they really be showing a preference for the top candidate? Given a vertical array of names, it may be impossible to distinguish the influences of temporal (or numerical) order from those of spatial position: spatial height and temporal primacy are perfectly confounded as voters read from the top to the bottom of a list. Both spatial height and temporary primacy might yield a tendency to vote for the candidate whose name is listed at the top of the list.

By examining name-order effects when names are arrayed horizontally, however, it may be possible to tease apart influences of temporal primacy and spatial position. In addition to associations between vertical space and positivity, linguistic and cultural conventions also suggest associations between "goodness" and horizontal space (e.g., "My right hand man"; "two left feet"). A series of experiments shows that people associate goodness with left-right space implicitly, but not always in the way cultural conventions suggest they should. Right-handers tend to associate "good" with "right" and "bad" with "left," consistent with idioms in language, but left-handers show the opposite implicit associations. For lefties, the left side is the "good" side of space, and the right side is the "bad" side. As a consequence of these implicit associations, people tend to evaluate things they encounter on their dominant side of a page or a computer screen more favorably. When asked to decide which of two products to buy, which job applicant to hire, or which alien creature looks more honest, intelligent, or attractive, right- and left-handers respond differently: right-handers tend to prefer the product, person, or creature presented on their right side, but left-handers tend to prefer the one on their left (Casasanto, 2009).

The association between "good" and one's dominant side of space was discovered through tests of the body-specificity hypothesis (Casasanto, 2009): the proposal that people with different kinds of bodies may form correspondingly different thoughts, feelings, and judgments (Casasanto, 2011, for review). The link between "good" and "dominant side" appears to be mediated by motor fluency. People associate "good" with the side of space on which they can habitually act more fluently, using their dominant hand, and "bad" with the side on which they act more clumsily using their nondominant hand (Casasanto \& Chrysikou, 2011). This association can be detected even when people make judgments orally without using their hands to respond, and it has been shown to influence people's reaction times for judging the meanings of positive and negative words (de la Vega, de Filippis, Lachmair, Dudschig, \& Kaup, 2012) and their memories for the locations of events with positive and negative emotional valence (Brunyé, Gardony, Mahoney, \& Taylor, 2012).

Beyond the laboratory, body-specific associations between space and valence have been observed in the speech and gestures of right- and left-handed U.S. presidential candidates during televised debates from the 2004 and 2008 elections (Casasanto \& Jasmin, 2010). For right-handers (Bush, Kerry), right-hand gestures were more strongly associated with positive-valence speech, and left-hand gestures with negative-valence speech. But the opposite associations were observed in left-handers' speech and gestures (McCain, Obama). Here, we investigated whether handednessbased implicit associations interact with the left-right placement of names on a ballot to bias people's voting behaviour.

If name-order effects in voting are, in fact, due to temporal or numerical sequence in which voters encounter the names on a ballot, then these effects should not differ between right- and 
left-handers. Regardless of whether names are arrayed vertically or horizontally, people in Englishspeaking cultures read from top to bottom and left to right, regardless of their handedness, so name-order effects should be the same. But if primacy effects are exclusively due to spatial position and not to temporal order, then left- and right-handers should show similar effects of name order with a vertical array but opposite effects of order with a horizontal array. Left-handers should manifest a tendency to vote for candidates who appear on the left, and right-handers should manifest a tendency to candidates who appear on the right. If both spatial position and temporal order bias voters' selections, then a hybrid effect should appear. For example, with horizontal presentation, all voters may be biased toward voting for the candidate whose name appears on the left (due to temporal ordering), and this bias may be stronger among left-handers than among right-handers (due to spatial position).

\section{Overview of the Study}

To permit testing these hypotheses, participants participated in a simulated election in an Internet survey. They read information about two hypothetical candidates and voted for one of them. Experimental manipulations varied the amount of information that voters received about the candidates, the order of the candidate names in the voting question, and whether the candidate names were presented vertically or horizontally. We explored the impact of a variety of purported moderators, including the cognitive skills, cognitive effort, ambivalence, and handedness of the voters and the orientations and positions of the candidates' names on the simulated ballot.

\section{Method}

\section{Sample}

Participants were a national sample of American adults recruited by Luth Research. ${ }^{3}$ From among 1.4 million members of Luth Research's survey panel (who had signed up to complete online surveys), a stratified random sample of 83,986 people was selected, with demographic strata specified to resemble the distributions of gender, age, household income, ethnicity, region, and education in the U.S. adult population according to the 2000 U.S. Census. E-mail invitations were sent to these individuals, and data were collected between October 7 and October 21, 2009, from 2,069 (completion rate $=2.5 \%$ ); 572 of these individuals answered questions used in the present study. We report results using data only from these individuals. ${ }^{4}$

The unweighted sample resembled the nation (as gauged by the 2009 Current Population Survey conducted by the U.S. Census Bureau, 2009) with regard to age, race, ethnicity, and gender but diverged from it with regard to education and income (compare columns 1 and 2 in Table 1). The participating participants underrepresented people with relatively little education and people with high incomes.

\footnotetext{
${ }^{3}$ Panel members were recruited via a variety of methods. Initially, random digit dial (RDD) telephone calls were made to invite a random sample of American adults to sign up to receive e-mail invitations to participate in surveys, yielding about 2,500 panel members. Additional telephone calls were made to individuals working in the information technology sector who were on professional lists; these calls yielded about 2,500 more panel members. These initial 5,000 panel members were offered a chance to win cash or gift certificates if they referred friends or family who might sign up to complete online surveys. Panel members were also recruited through online ads and through e-mails sent by companies and organizations with which the potential panelist was affiliated.

${ }^{4}$ This excludes 35 participants who did not answer the following question accurately in the middle of the survey: "To help us make sure our website is working properly, please select the number seven below." The response options were integers ranging from 1 to 7.
} 
Table 1. Demographics of the Weighted and Unweighted Samples Compared to the Population

\begin{tabular}{|c|c|c|c|}
\hline Variable & $\begin{array}{c}\text { Unweighted Survey } \\
\text { Sample }\end{array}$ & $\begin{array}{c}2009 \text { Current } \\
\text { Population Survey }\end{array}$ & $\begin{array}{c}\text { Weighted Survey } \\
\text { Sample }\end{array}$ \\
\hline \multicolumn{4}{|l|}{ Age } \\
\hline $18-24$ & $8.5 \%$ & $12.6 \%$ & $12.6 \%$ \\
\hline $25-34$ & 18.5 & 17.9 & 17.9 \\
\hline $35-44$ & 15.6 & 18.2 & 18.2 \\
\hline $45-54$ & 19.2 & 19.5 & 19.5 \\
\hline $55-64$ & 17.6 & 15.1 & 15.1 \\
\hline 65 and up & 20.5 & 16.6 & 16.6 \\
\hline Total & $100.0 \%$ & $100.0 \%$ & $100.0 \%$ \\
\hline \multicolumn{4}{|l|}{ Race } \\
\hline White & $81.2 \%$ & $81.2 \%$ & $81.4 \%$ \\
\hline African American & 12.0 & 11.8 & 11.8 \\
\hline Other/Multiple & 6.8 & 7.0 & 6.9 \\
\hline Total & $100.0 \%$ & $100.0 \%$ & $100.0 \%$ \\
\hline \multicolumn{4}{|l|}{ Hispanic Origin } \\
\hline Non-Hispanic & $91.1 \%$ & $86.3 \%$ & $86.1 \%$ \\
\hline Hispanic & 8.9 & 13.7 & 13.9 \\
\hline Total & $100.0 \%$ & $100.0 \%$ & $100.0 \%$ \\
\hline \multicolumn{4}{|l|}{ Gender } \\
\hline Female & $44.0 \%$ & $51.5 \%$ & $51.3 \%$ \\
\hline Male & 56.0 & 48.5 & 48.7 \\
\hline Total & $100.0 \%$ & $100.0 \%$ & $100.0 \%$ \\
\hline \multicolumn{4}{|l|}{ Income } \\
\hline$<\$ 20,000$ & $17.6 \%$ & $13.4 \%$ & $12.8 \%$ \\
\hline$\$ 20,000-\$ 34,999$ & 17.2 & 14.7 & 14.5 \\
\hline$\$ 35,000-\$ 49,999$ & 15.8 & 13.6 & 13.3 \\
\hline$\$ 50,000-\$ 74,999$ & 25.2 & 20.0 & 19.9 \\
\hline$\$ 75,000-\$ 99,999$ & 11.6 & 13.8 & 13.9 \\
\hline$\geq \$ 100,000$ & 12.5 & 25.4 & 25.6 \\
\hline Total & $100.0 \%$ & $100.0 \%$ & $100.0 \%$ \\
\hline \multicolumn{4}{|l|}{ Education } \\
\hline No High School Degree & $2.5 \%$ & $14.1 \%$ & $12.6 \%$ \\
\hline High School Degree & 18.7 & 30.9 & 31.4 \\
\hline Some College/AA Degree & 38.8 & 28.0 & 28.4 \\
\hline BA Degree or More & 40.0 & 27.1 & 27.5 \\
\hline Total & $100.0 \%$ & $100.0 \%$ & $100.0 \%$ \\
\hline$N$ & 572 & 239,205 & 572 \\
\hline
\end{tabular}

a Source: U.S. Census Bureau Current Population Survey, Annual Social and Economic Supplement, March 2009. (Adult population only)

\section{Weights}

To correct for these demographic discrepancies, we followed procedures recommended by the American National Election Studies (ANES) for building weights optimally (DeBell \& Krosnick, 2009) using software called the ANES Weighting Algorithm (the AWA; Pasek, DeBell, \& Krosnick, 2010). The AWA uses an iterative, multiplicative approach to generate weights, which adjusts the vector of weights in each iteration by comparing the sample marginals with the population marginals (Pasek, 2010). Age (in six categories), education level (four categories), household income (six categories), race (White, African American, other/multiple), Hispanic ethnicity (Hispanic, nonHispanic), and gender (female, male) were used as the raking variables. The weights were capped at 
5.00. The procedure corrected well for the discrepancies between the study participants and the population; the poststratified participants closely resembled the nation (compare the second and third columns of Table 1).

\section{Questionnaire Overview}

Participants first answered general questions assessing political interest, party identification, and preferences on policy issues. Participants were then told that they would be asked to vote after reading a series of statements made by two hypothetical candidates running hypothetically for a seat in the U.S. Congress: Alan Mitchell and Robert Swanson. ${ }^{5}$ Each screen displayed one statement from one candidate, and participants reported how much they agreed or disagreed with each statement. On every issue for every respondent, Alan Mitchell's position was presented before Robert Swanson's. ${ }^{6}$ After reading all of the statements, participants voted for one of the two candidates. Additional questions assessed ambivalence, cognitive effort, political knowledge, and demographics.

\section{Experimental Design}

Each participant was randomly assigned to receive either a large amount of information about the candidates or a small amount, either to see Mitchell's name listed first or to see Swanson's listed first in the vote question, and to see the candidates' names either in a horizontal array or in a vertical array. Information volume was manipulated by assigning some participants to read about the candidates' positions on four issues (health care, immigration, stem cell research, and education), and the remaining participants read about those four issues plus four others: gun control, global warming and the environment, the war in Iraq, and tax reform. These manipulations were represented in our analysis by three binary variables: Name order (coded 0 for people who saw Swanson's name first and 1 for people who saw Mitchell's name first), Information (coded 0 for people who read about eight issues and 1 for people who read about four issues), and Array (coded 0 for people who saw the candidates' names vertically and 1 for people who saw the names horizontally).

The information presented to each participant was designed so that his or her own positions on the issue were expressed by Mitchell, and Swanson always took the opposite positions. To accomplish this, each participant's answers to policy attitude questions asked early in the survey were used to determine which candidate statements would be attributed to which candidate in the information presentation that the participant saw later. For example, if a participant opposed school vouchers (in response to this question: "Do you favor or oppose the government giving vouchers to parents to pay for some of the fees for a child to attend a private school instead of attending his or her local public school?"), that participant later read the following statements by the candidates on the issue of education:

Alan Mitchell: "Public schools are an important component of American society. We should try to improve public schools rather than destroying them with vouchers."

Robert Swanson: "I believe that the government should not be in the business of running schools. I think parents should receive state-funded vouchers, which would pay for any type of schooling the parents choose."

\footnotetext{
5 "Alan" is the first name of $0.2 \%$ of Americans; "Robert" is the first name of 3.1\%; "Swanson" is the last name of $0.02 \%$ of Americans; and "Mitchell" is the last name of $0.1 \%$ (U.S. Census Bureau, 2010). Thus, these names are roughly comparable in terms of familiarity and popularity.

${ }^{6}$ Bruine de Bruin (2005) found that objects presented later in a sequence were evaluated more positively. Thus, perhaps presenting Swanson's issue positions after Mitchell's advantaged Swanson. This was a constant across all participants and was therefore not confounded with any other variables of interest here.
} 


\section{Measures}

Vote choice. Participants were asked: "Based on what you read, if an election were held today and you had to choose between the two candidates, who would you vote for?" Responses were coded 1 for Mitchell and 0 for Swanson.

Ambivalence. Immediately after answering the vote-choice question, participants reported how conflicted they felt when choosing between the two candidates and how hard it was to make the choice, on 5-point rating scales (extremely conflicted/hard, very conflicted/hard, moderately conflicted/hard, slightly conflicted/hard, not conflicted/hard at all). This is a meta-psychological measure of ambivalence (Holbrook \& Krosnick, 2005), which taps the subjective experience of evaluative conflict regarding an object (see Cacioppo, Gardner, \& Berntson, 1997; Thompson, Zanna, \& Griffin, 1995). Responses were coded to range from 0 (indicating low ambivalence) to 1 (indicating high ambivalence) and were averaged to yield an index of ambivalence, which was dichotomized at the median. ${ }^{7}$ Participants who were high in ambivalence were coded 1 , and participants who were low in ambivalence were coded 0 .

Cognitive skills. Educational attainment was used as a proxy measure of cognitive skills, because years of education correlate extremely strongly with scores on direct tests of cognitive skills (Ceci, 1996). Educational attainment was measured by asking participants to report the highest grade in school they had completed or the highest degree they had received. Participants who had not graduated from high school were coded 1 ("Low Cognitive Skills"), and participants who had graduated from high school were coded 0 ("High Cognitive Skills").

Cognitive effort. Two questions gauged the amount of effort that participants put into the candidate-evaluation task: "How carefully did you think when deciding which candidate to vote for?" (extremely carefully, very carefully, moderately carefully, slightly carefully, and not carefully at all), and "How hard did you work to make sure you voted for the best candidate?" (extremely hard, very hard, moderately hard, slightly hard, and not hard at all). Responses to both questions were coded $1, .75, .5, .25$, and 0 , respectively, and answers to the two questions were averaged to yield an index of cognitive effort, which was dichotomized at the midpoint and coded 0 ("High Cognitive Effort") and 1 ("Low Cognitive Effort").

Handedness. Participants were asked, "Are you left or right handed?" Left-handed participants were coded 1 , and all others were coded 0 .

Demographic variables. Each participant reported his or her year of birth, race, Hispanic ethnicity, gender, and household income at the end of the survey (question wordings and codings appear in the appendix).

\section{Results}

Alan Mitchell received 90.6\% ( $\mathrm{N}=247)$ of the votes when he was listed first and only $75.3 \%$ of the votes when he was listed second $(\mathrm{N}=312$; see row 1 of Table 2). This 15.3 percentage point difference is a statistically significant primacy effect $\left(\chi^{2}(1)=21.48, p=.00\right){ }^{8}$

As expected, the first position advantage was stronger among participants who were given less information about the candidates $(b=.19, p=.01$; see column 1 of Table 3$) .{ }^{9}$ Participants who were

\footnotetext{
${ }^{7}$ Ambivalence, cognitive skills, and cognitive effort were dichotomized to simplify presentation and analysis. When the moderators were treated as continuous variables, the main results remained essentially unchanged.

${ }^{8}$ All observed differences for directional hypotheses were in the expected direction, so we report one-tailed p-values for these tests. All other reported $p$-values are two-tailed.

${ }^{9}$ Although logit and probit models are popular estimation strategies for binary dependent variables such as this, the linear probability model (LPM), estimated by ordinary least squares, is increasingly popular in econometric analyses (e.g., Angrist \& Pischke, 2009). Used with the correct standard errors, linear probability models produce unbiased estimates when coefficients from logit or probit are flawed (Angrist \& Pischke, 2009; Freedman, 2008).
} 
Table 2. Alan Mitchell's Vote Share Under Different Name Orders

\begin{tabular}{|c|c|c|c|}
\hline Participant Group & $\begin{array}{l}\text { Alan Mitchell } \\
\text { Listed First }\end{array}$ & $\begin{array}{l}\text { Alan Mitchell } \\
\text { Listed Second }\end{array}$ & Difference \\
\hline All Participants & $\begin{array}{l}90.6 \% \\
(247)\end{array}$ & $\begin{array}{l}75.3 \% \\
(312)\end{array}$ & $15.3 * *$ \\
\hline Low-Information Condition & $\begin{array}{c}94.8 \% \\
(131)\end{array}$ & $\begin{array}{c}66.5 \% \\
(157)\end{array}$ & $28.3^{* *}$ \\
\hline High-Information Condition & $\begin{array}{l}85.9 \% \\
(116)\end{array}$ & $\begin{array}{l}84.2 \% \\
(155)\end{array}$ & 1.7 \\
\hline High-Ambivalence Participants & $\begin{array}{c}86.0 \% \\
(123)\end{array}$ & $\begin{array}{c}62.1 \% \\
(133)\end{array}$ & $23.9^{* *}$ \\
\hline Low-Ambivalence Participants & $\begin{array}{c}95.1 \% \\
(124)\end{array}$ & $\begin{array}{l}85.1 \% \\
(179)\end{array}$ & $10.0^{*}$ \\
\hline Low Cognitive Skills Participants & $\begin{array}{c}94.7 \% \\
(97)\end{array}$ & $\begin{array}{c}73.0 \% \\
(138)\end{array}$ & $21.7 * *$ \\
\hline High Cognitive Skills Participants & $\begin{array}{c}88.3 \% \\
(144)\end{array}$ & $\begin{array}{c}78.3 \% \\
(162)\end{array}$ & $10.0^{*}$ \\
\hline Low Cognitive Effort Participants & $\begin{array}{c}92.4 \% \\
(58)\end{array}$ & $\begin{array}{c}63.8 \% \\
(61)\end{array}$ & $28.6^{* *}$ \\
\hline High Cognitive Effort Participants & $\begin{array}{l}90.1 \% \\
(189)\end{array}$ & $\begin{array}{c}78.1 \% \\
(251)\end{array}$ & $12.0^{* *}$ \\
\hline Horizontal Name Array Condition & $\begin{array}{c}93.4 \% \\
(128)\end{array}$ & $\begin{array}{l}70.7 \% \\
(141)\end{array}$ & $22.7 * *$ \\
\hline Vertical Name Array Condition & $\begin{array}{l}87.7 \% \\
(119)\end{array}$ & $\begin{array}{l}79.1 \% \\
(171)\end{array}$ & 8.6 \\
\hline Horizontal Name Array-Left Handed & $\begin{array}{c}100.0 \% \\
(13)\end{array}$ & $\begin{array}{c}63.8 \% \\
(18)\end{array}$ & 36.2 \\
\hline Horizontal Name Array-Right Handed & $\begin{array}{c}92.3 \% \\
(110)\end{array}$ & $\begin{array}{l}71.3 \% \\
(117)\end{array}$ & $21.0^{* *}$ \\
\hline Vertical Name Array-Left Handed & $\begin{array}{c}100.0 \% \\
(12)\end{array}$ & $\begin{array}{c}92.3 \% \\
(20)\end{array}$ & 7.7 \\
\hline Vertical Name Array-Right Handed & $\begin{array}{c}86.9 \% \\
(103)\end{array}$ & $\begin{array}{c}78.9 \% \\
(146)\end{array}$ & 8.0 \\
\hline
\end{tabular}

Note. Ns for each cell appear under percentages. $p$-values were obtained from the $F$ statistic that corrects the Pearson $\chi^{2}$ statistic for the survey design.

$* p<.05, * * p<.01$

shown the candidates' opinions on only four issues manifested a strong and significant primacy effect of 28.3 percentage points $\left(\chi^{2}(1)=34.82, p=.00\right.$; see row 2 of Table 2$)$. In contrast, participants who were shown the candidates' opinions on eight issues manifested a small and nonsignificant difference of 1.7 percentage points $\left(\chi^{2}(1)=0.15, p=.75\right.$; see row 3 of Table 2$)$.

Also as expected, the primacy effect was much larger (23.9 percentage points) among participants who were highly ambivalent about their candidate choice $\left(\chi^{2}(1)=19.53, p=.00\right.$; see row 4 of Table 2) than among low-ambivalence participants (10.0 percentage points, $\chi^{2}(1)=7.54, p=.04$; see row 5 of Table 2). The difference between these groups was on the cusp of marginal significance $(b=.12, p=.10$; see column 1 of Table 3$)$.

Consistent with expectations, the primacy effect was more pronounced among participants with less education (21.7 percentage points, $\chi^{2}(1)=8.78, p=.00$; see row 6 of Table 2 ) than among participants with more education (10.0 percentage points, $\chi^{2}(1)=7.62, p=.05$; see row 7 of Table 2 ). The difference between these two groups was significant $(b=.14, p=.04$; see column 1 of Table 3 ).

As expected, among participants who devoted little cognitive effort to the task of evaluating the candidates, the primacy effect was a highly significant 28.6 percentage points $\left(\chi^{2}(1)=15.50, p=.00\right.$; 
Table 3. Predicting the Probability of Voting for Alan Mitchell

\begin{tabular}{|c|c|c|c|}
\hline Predictor & Model 1 & Model 2 & Model 3 \\
\hline \multicolumn{4}{|l|}{ Demographic Controls } \\
\hline Age & $\begin{array}{c}.00 \\
(.00)\end{array}$ & $\begin{array}{c}.00 \\
(.00)\end{array}$ & $\begin{array}{c}.00 \\
(.00)\end{array}$ \\
\hline Black & $\begin{array}{c}-.01 \\
(.07)\end{array}$ & $\begin{array}{c}-.02 \\
(.07)\end{array}$ & $\begin{array}{c}-.02 \\
(.07)\end{array}$ \\
\hline Hispanic & $\begin{array}{c}-.01 \\
(.11)\end{array}$ & $\begin{array}{c}-.00 \\
(.11)\end{array}$ & $\begin{array}{l}.01 \\
(.11)\end{array}$ \\
\hline Female & $\begin{array}{l}.00 \\
(.07)\end{array}$ & $\begin{array}{c}-.01 \\
(.07)\end{array}$ & $\begin{array}{c}-.01 \\
(.07)\end{array}$ \\
\hline Lefty & - & $\begin{array}{c}.08 \\
(.10)\end{array}$ & $\begin{array}{l}.22^{*} \\
(.09)\end{array}$ \\
\hline \multicolumn{4}{|l|}{ Main Effects of Moderators } \\
\hline Low-Information Condition & $\begin{array}{c}-.13 \dagger \\
(.07)\end{array}$ & $\begin{array}{c}-.13 \dagger \\
(.07)\end{array}$ & $\begin{array}{c}-.12 \dagger \\
(.07)\end{array}$ \\
\hline High Ambivalence & $\begin{array}{c}-.20 * * \\
(.08)\end{array}$ & $\begin{array}{l}-.21 * * \\
(.08)\end{array}$ & $\begin{array}{c}-.21 * * \\
(.08)\end{array}$ \\
\hline Low Cognitive Skill & $\begin{array}{l}-.09 \\
(.07)\end{array}$ & $\begin{array}{l}-.09 \\
(.07)\end{array}$ & $\begin{array}{c}-.10 \\
(.07)\end{array}$ \\
\hline Low Cognitive Effort & $\begin{array}{c}-.12 \\
(.09)\end{array}$ & $\begin{array}{c}-.12 \\
(.09)\end{array}$ & $\begin{array}{c}-.11 \\
(.08)\end{array}$ \\
\hline Horizontal Array & $\begin{array}{l}-.07 \\
(.07)\end{array}$ & $\begin{array}{l}-.07 \\
(.07)\end{array}$ & $\begin{array}{c}-.03 \\
(.07)\end{array}$ \\
\hline Lefty $\times$ Horizontal Array & - & - & $\begin{array}{c}-.34 * \\
(.16)\end{array}$ \\
\hline \multicolumn{4}{|l|}{ Name Order Main Effect } \\
\hline Name Order & $\begin{array}{l}-.09 \\
(.16)\end{array}$ & $\begin{array}{c}-.10 \\
(.16)\end{array}$ & $\begin{array}{l}-.08 \\
(.16)\end{array}$ \\
\hline \multicolumn{4}{|l|}{ Demographic Interactions } \\
\hline Name Order $\times$ Age & $\begin{array}{c}-.02 \\
(.02)\end{array}$ & $\begin{array}{c}-.02 \\
(.02)\end{array}$ & $\begin{array}{c}-.02 \\
(.02)\end{array}$ \\
\hline Name Order $\times$ Hispanic & $\begin{array}{l}.08 \\
(.12)\end{array}$ & $\begin{array}{l}.08 \\
(.12)\end{array}$ & $\begin{array}{c}.07 \\
(.12)\end{array}$ \\
\hline Name Order $\times$ Black & $\begin{array}{l}.07 \\
(.09)\end{array}$ & $\begin{array}{c}.08 \\
(.09)\end{array}$ & $\begin{array}{l}.09 \\
(.09)\end{array}$ \\
\hline Name Order $\times$ Female & $\begin{array}{l}.01 \\
(.08)\end{array}$ & $\begin{array}{l}.02 \\
(.08)\end{array}$ & $\begin{array}{c}.02 \\
(.08)\end{array}$ \\
\hline \multicolumn{4}{|l|}{ Moderator Interactions } \\
\hline Name Order $\times$ Low Information & $\begin{array}{l}.19 * * \\
(.08)\end{array}$ & $\begin{array}{l}.19 * \\
(.08)\end{array}$ & $\begin{array}{l}.19^{*} \\
(.08)\end{array}$ \\
\hline Name Order $\times$ High Ambivalence & $\begin{array}{l}.12 \dagger \\
(.09)\end{array}$ & $\begin{array}{l}.13 \dagger \\
(.09)\end{array}$ & $\begin{array}{l}.13 \dagger \\
(.09)\end{array}$ \\
\hline Name Order $\times$ Low Cognitive Skill & $\begin{array}{l}.14 * \\
(.08)\end{array}$ & $\begin{array}{c}.15^{*} \\
(.08)\end{array}$ & $\begin{array}{l}.16^{*} \\
(.08)\end{array}$ \\
\hline Name Order $\times$ Low Cognitive Effort & $\begin{array}{l}.14 \dagger \\
(.10)\end{array}$ & $\begin{array}{l}.15 \dagger \\
(.10)\end{array}$ & $\begin{array}{l}.14 \dagger \\
(.10)\end{array}$ \\
\hline Name Order $\times$ Horizontal Array & $\begin{array}{l}.13 \dagger \\
(.08)\end{array}$ & $\begin{array}{l}.13 \dagger \\
(.08)\end{array}$ & $\begin{array}{l}.10 \\
(.09)\end{array}$ \\
\hline Name Order $\times$ Lefty & - & $\begin{array}{c}.03 \\
(.10)\end{array}$ & $\begin{array}{c}-.08 \\
(.10)\end{array}$ \\
\hline Name Order $\times$ Lefty $\times$ Horizontal Array & - & - & $\begin{array}{c}.28 \dagger \\
(.17)\end{array}$ \\
\hline Constant & $\begin{array}{l}.90 * * \\
(.15)\end{array}$ & $\begin{array}{l}.89 * * \\
(.15)\end{array}$ & $\begin{array}{l}.87 * * \\
(.15)\end{array}$ \\
\hline$N$ & 547 & 546 & 546 \\
\hline
\end{tabular}

Note. Cell entries are unstandardized regression coefficients with robust standard errors underneath in parentheses. ${ }^{*} p<.05, * * p<.01$, $\uparrow p<.10$ 
see row 8 of Table 2). Among participants who devoted considerable cognitive effort, a weaker primacy effect of 12.0 percentage points appeared $\left(\chi^{2}(1)=10.84, p=.01\right.$; see row 9 of Table 2$)$. The moderating effect of cognitive effort was marginally significant $(b=.14, p=.08$; see column 1 of Table 3).

The primacy effect was sizable and statistically significant among participants who saw the candidate names arrayed horizontally (22.7 percentage points, $\chi^{2}(1)=23.47, p=.00$; see row 10 of Table 2). But among participants who saw the candidates' names arrayed vertically, the first-position advantage of 8.6 percentage points was not significant $\left(\chi^{2}(1)=3.54, p=.14\right)$; see row 11 of Table 2$)$. These two effect sizes were marginally significantly different from one another $(b=.13, p=.06$; see column 1 of Table 3 ).

When handedness and its interaction with name array were added to the regression (see columns 2 and 3 of Table 3), the baseline effect of name order, which describes the order effect among participants (1) who had much information about the candidates, (2) were not ambivalent about their choice, (3) were more educated, (4) expended much cognitive effort, (5) saw a vertical array of names, and (6) were right-handed was not distinguishable from zero $(b=-.10, p=.55$; see column 2 of Table 3). And as expected, the primacy effect was significantly larger as information volume decreased ( $b=.19, p=.01$; see column 2 of Table 3 ), was marginally significantly larger among people higher in ambivalence $(b=.13, p=.08$; see column 2 of Table 3$)$, was significantly larger among more educated people ( $b=.15, p=.03$; see column 2 of Table 3$)$, and was marginally significantly larger among people who expended less cognitive effort $(b=.15, p=.08$; see column 2 of Table 3 ). The size of the name-order effect was marginally significantly greater among people who saw a horizontal array of candidate names than among people who saw a vertical array $(b=.13, p=.06$; see column 2 of Table 3). Right-handed people and left-handed people did not differ significantly in terms of the order effect under conditions of vertical presentation $(b=.03, p=.75$; see column 2 of Table 3$)$.

Consistent with expectations, a marginally significant three-way interaction of name order by left-handedness by array appeared ( $b=.28, p=.05$, see column 3 of Table 3$)$. When the candidates' names were arrayed horizontally, the name-order effect was marginally significantly greater among left-handers than among right-handers $(b=.21, p=.08$; see column 2 of Table 4). But when candidates' names were arrayed vertically, the name-order effect was not significant among left-handers (7.7 percentage points; $\chi^{2}=1.12, p=.30, \mathrm{~N}=32$; see row 14 of Table 2 ) or among right-handers (8.0 percentage points; $\chi^{2}=2.64, p=.21, \mathrm{~N}=249$; see row 15 of Table 2) and did not differ between these two groups $(b=-.05, p=.62$, see column 3 of Table 4$)$.

\section{Discussion}

\section{Summary of Findings}

In this study, candidates gained 15 percentage points by virtue of being listed first. This finding resonates with past studies that also found primacy effects in real elections, though the effect size here is much larger than has typically been observed previously (e.g., Koppell \& Steen, 2004; Krosnick et al., 2004; Miller \& Krosnick, 1998).

The effects of the moderators examined here seem quite substantial and theoretically informative. Under the conditions where the name-order effect was expected to be strongest-among people with little information, high ambivalence, lower cognitive skills, and less cognitive effort-the primacy effect was huge $(b=.63, p=.00)$. And under the conditions where the effect was expected to be smallest - among people with a lot of information, no ambivalence, high cognitive skills, and higher cognitive effort-the name-order effect disappeared completely $(b=-.09, p=.57$; see column 1 of Table 3 ). Thus, even this limited set of moderators seems to have identified conditions under which the effect thrived versus vanished. 
Table 4. Predictors of Voting for Alan Mitchell Separating by Horizontal and Vertical Name Array Conditions

\begin{tabular}{|c|c|c|c|}
\hline Predictor & Full Sample & Horizontal Only & Vertical Only \\
\hline \multicolumn{4}{|l|}{ Demographic Controls } \\
\hline Age & $\begin{array}{c}.00 \\
(.00)\end{array}$ & $\begin{array}{c}.00 \\
(.00)\end{array}$ & $\begin{array}{c}.00 \\
(.00)\end{array}$ \\
\hline Black & $\begin{array}{c}-.02 \\
(.07)\end{array}$ & $\begin{array}{c}-.16 \\
(.10)\end{array}$ & $\begin{array}{c}.10 \\
(.09)\end{array}$ \\
\hline Hispanic & $\begin{array}{c}-.00 \\
(.11)\end{array}$ & $\begin{array}{c}-.19 \\
(.16)\end{array}$ & $\begin{array}{c}.25 * \\
(.09)\end{array}$ \\
\hline Female & $\begin{array}{c}-.10 \\
(.07)\end{array}$ & $\begin{array}{c}-.10 \\
(.09)\end{array}$ & $\begin{array}{c}.08 \\
(.09)\end{array}$ \\
\hline Lefty & $\begin{array}{c}.08 \\
(.10)\end{array}$ & $\begin{array}{c}-.13 \\
(.15)\end{array}$ & $\begin{array}{c}.20^{*} \\
(.09)\end{array}$ \\
\hline \multicolumn{4}{|l|}{ Main Effects of Moderators } \\
\hline Low-Information Condition & $\begin{array}{c}-.13 \dagger \\
(.07)\end{array}$ & $\begin{array}{c}-.12 \\
(.09)\end{array}$ & $\begin{array}{c}-.11 \\
(.09)\end{array}$ \\
\hline High Ambivalence & $\begin{array}{c}-.21^{* *} \\
(.08)\end{array}$ & $\begin{array}{c}-.24 * \\
(.10)\end{array}$ & $\begin{array}{c}-.14 \\
(.10)\end{array}$ \\
\hline Low Cognitive Skills & $\begin{array}{c}-.09 \\
(.07)\end{array}$ & $\begin{array}{c}-.20 \dagger \\
(.10)\end{array}$ & $\begin{array}{c}-.06 \\
(.09)\end{array}$ \\
\hline Low Cognitive Effort & $\begin{array}{c}-.12 \\
(.09)\end{array}$ & $\begin{array}{c}.02 \\
(.12)\end{array}$ & $\begin{array}{c}-.24 * \\
(.11)\end{array}$ \\
\hline Horizontal Array & $\begin{array}{c}-.07 \\
(.07)\end{array}$ & - & - \\
\hline \multicolumn{4}{|l|}{ Name-Order Main Effect } \\
\hline Name Order & $\begin{array}{c}-.10 \\
(.16)\end{array}$ & $\begin{array}{c}-.15 \\
(.17)\end{array}$ & $\begin{array}{c}.06 \\
(.22)\end{array}$ \\
\hline \multicolumn{4}{|l|}{ Demographic Interactions } \\
\hline Name Order $\times$ Age & $\begin{array}{c}-.02 \\
(.02)\end{array}$ & $\begin{array}{c}-.01 \\
(.03)\end{array}$ & $\begin{array}{c}-.03 \\
(.03)\end{array}$ \\
\hline Name Order $\times$ Hispanic & $\begin{array}{c}.08 \\
(.12)\end{array}$ & $\begin{array}{c}.26 \\
(.16)\end{array}$ & $\begin{array}{c}-.17 \\
(.11)\end{array}$ \\
\hline Name Order $\times$ Black & $\begin{array}{c}.08 \\
(.09)\end{array}$ & $\begin{array}{l}.16 \\
(.12)\end{array}$ & $\begin{array}{c}.09 \\
(.11)\end{array}$ \\
\hline Name Order $\times$ Female & $\begin{array}{c}.02 \\
(.08)\end{array}$ & $\begin{array}{l}.10 \\
(.10)\end{array}$ & $\begin{array}{c}-.07 \\
(.12)\end{array}$ \\
\hline \multicolumn{4}{|l|}{ Moderator Interactions } \\
\hline Name Order $\times$ Low Information & $\begin{array}{c}.19 * \\
(.08)\end{array}$ & $\begin{array}{c}.20 * \\
(.10)\end{array}$ & $\begin{array}{l}.16 \dagger \\
(.11)\end{array}$ \\
\hline Name Order $\times$ High Ambivalence & $\begin{array}{c}.13 \dagger \\
(.09)\end{array}$ & $\begin{array}{l}.17 \dagger \\
(.12)\end{array}$ & $\begin{array}{c}.03 \\
(.13)\end{array}$ \\
\hline Name Order $\times$ Low Cognitive Skills & $\begin{array}{c}.15 * \\
(.08)\end{array}$ & $\begin{array}{c}.25 * \\
(.12)\end{array}$ & $\begin{array}{c}.11 \\
(.11)\end{array}$ \\
\hline Name Order $\times$ Low Cognitive Effort & $\begin{array}{c}.15 \dagger \\
(.10)\end{array}$ & $\begin{array}{c}-.03 \\
(.15)\end{array}$ & $\begin{array}{l}.31 * * \\
(.13)\end{array}$ \\
\hline Name Order $\times$ Horizontal Array & $\begin{array}{c}.13 \\
(.08)\end{array}$ & - & - \\
\hline Name Order $\times$ Lefty & $\begin{array}{c}.03 \\
(.10)\end{array}$ & $\begin{array}{c}.21 \dagger \\
(.15)\end{array}$ & $\begin{array}{c}-.05 \\
(.10)\end{array}$ \\
\hline Constant & $\begin{array}{l}.89 * * \\
(.15)\end{array}$ & $\begin{array}{l}.95^{* *} \\
(.14)\end{array}$ & $\begin{array}{l}.75^{* *} * \\
(.22)\end{array}$ \\
\hline$N$ & 546 & 266 & 280 \\
\hline
\end{tabular}

Note. Cell entries are unstandardized regression coefficients with robust standard errors underneath in parentheses. $* p<.05, * * p<.01, \dagger p<.10$ 
The present evidence of moderation by information volume resonates with past studies that found weaker name-order effects in races that received more news media attention (Miller \& Krosnick, 1998) and strengthens the case for this moderator by documenting causal influence of information volume. This study is the first to provide direct evidence of the role of ambivalence in moderating name-order effects and thereby offer support for the claim that name-order effects sometimes occur because a voter feels torn between the candidates.

This study was also the first to document the individual-level influences of cognitive skills and cognitive effort in moderating the primacy effect in voting. By showing that greater cognitive skills and greater cognitive effort were associated with reduced name-order effects, the present study suggests that such effects may depend not only on how much voters know about the candidates but also on their ability and willingness to make use of the available information.

The name-order effect was large when names were displayed horizontally but not when names were arrayed vertically. Under horizontal-presentation conditions, left-handers showed a greater tendency toward a primacy effect than did right-handers. Presumably, left-handers favored the candidate who appeared on the left in part because his name appeared on their dominant side (i.e., their "good" side of space), consistent with previous tests of the body-specificity hypothesis (Casasanto, 2009).

The effect of handedness is informative about the cognitive underpinnings of the name-order effect. The present data cannot be fully explained by the sequential order in which participants read the candidates' names. If the primacy effect was driven by sequential order alone, the effect should not have varied with handedness, since both right- and left-handed English speakers read from left to right (see Maass, Pagani, \& Berta, 2007, on directional bias by language culture). Therefore, it appears that implicit associations between emotional valence and left-right spatial position (which differ between left-handed and right-handed people) are partly responsible for the name-order effect observed here. That is, two biases appear to have been at work here: an effect of spatial position, which is rooted in handedness (see Casasanto, 2011, for review), and a sequential effect, rooted in the culture-specific convention of reading from left to right. The roles of the spatial arrangement of candidates' names and of voters' handedness as moderators of the name-order effect merit further investigation.

\section{Limitations and Future Research}

A few aspects of this study suggest hesitation before broadly generalizing the findings. First, the participants were not a representative sample of people who vote in elections. In real elections, people who have little information about the candidates and are minimally interested may choose not to vote at all. This natural filtering process is not reflected in the present study, since all participants were led into the virtual voting booth. This may be a reason why the magnitudes of the name-order effects and the strength of the moderators' effects may be considerably lessened in real elections.

Second, the simulated nature of the election raises questions about its resemblance to real elections. In this study, participants read verbal statements by the candidates. Cues such as their party identifications, endorsements, incumbency status, faces, and voices-all factors that may influence election outcomes - were not provided to the participants. Furthermore, unlike in some elections, the candidates' names were displayed in the vote question without party affiliations next to them. This suggests caution in generalizing our findings to all elections, especially the major elections that display the party affiliation of candidates.

However, past studies have found primacy effects in real elections where candidates' party affiliations were listed on the ballot (Ho \& Imai, 2008; Miller \& Krosnick, 1998), so it seems unlikely that adding party affiliations would have completely eliminated the name-order effects we saw in the present study. The size of the effect might have become smaller than what we see here (see 
Miller \& Krosnick, 1998), and the effect might manifest conditionally (see Ho \& Imai, 2008), but the order effect seems likely to persist. Presenting other information about the candidates, such as photographs of them (see, for example, Banducci, Karp, Thrasher, \& Rallings, 2008), might reduce the magnitude of the order effect and the magnitudes of moderation observed here. These factors remain to be studied experimentally in the future.

Lastly, because this study examined a two-candidate election, we cannot reach conclusions about races with more candidates. However, in a study of two-, three-, four-, and five-choice options of wine samples, a primacy effect was found to be similarly large across all of the choice sets (Mantonakis et al., 2009). So the same may be true for the number of candidates in a race.

\section{Implications of the Findings}

The policy implications of these results seem clear. In order to prevent giving an advantage to any particular competitor, candidates' names on ballots should be rotated across electoral units so that each name appears in the first position for approximately equal numbers of voters. This may be especially important for elections held in countries with compulsory voting, such as Australia. Perhaps more voters there cast ballots without needed information than would occur in countries where such citizens can choose not to vote. In Australia, all voters see candidate names in a single random order, which gives a consistent advantage to the candidate lucky enough to end up at the top of the list (King \& Leigh, 2009). In the United States, some states' (e.g., Ohio, North Dakota, Montana, Idaho, and Kansas) electoral laws require name rotation across precincts; Krosnick et al., 2004). Other states, such as California, rotate name orders for only some races. But the majority of the states do not implement procedures to safeguard against biasing impact of name-order effects. The present findings, coupled with those of other studies, suggest that these states should reconsider their voting methodologies.

By casting light on the psychological processes likely to be responsible for the name-order effect in elections, the present findings bring other remedial strategies to mind. Lack of information, ambivalence, lack of cognitive skills, and lack of cognitive effort all appear to be at work. The present findings regarding information volume and cognitive effort suggest that engaging the public in learning about candidates and equipping people with lots of substantive information may ameliorate name-order effect. It is likely to be difficult if not impossible to eliminate ambivalence, and cognitive skills are likely to be relatively fixed attributes of individuals, so they may not be of practical value when seeking to minimize the impact of name order.

This is the first study to show a stronger primacy effect on voting under horizontal presentation than under vertical presentation, and this finding should be viewed with caution. If this pattern replicates in subsequent studies, the practical implications seem clear. Candidates' names should be arrayed vertically on ballots, not horizontally, to avoid exacerbating the name-order effect and to avoid introducing different biases for right- and left-handed voters.

Lastly, the present findings add to the psychological literature on order effects in judgment. Many studies have explored how the order of choices influences people's decisions (e.g., Fazio, Powell, \& Williams, 1989), and the cognitive mechanisms underlying order effects appear to vary, depending on the context and nature of the judgment involved. For example, order effects in selections of navigational routes (Christenfeld, 1995) or food products (Coney, 1977; Dean, 1980; Fazio et al., 1989) or knowledge tests (Atwell \& Wells, 1937; Clark, 1956) seem to occur for quite different reasons from those underlying name-order effects in elections. By illuminating how name-order effects are moderated by information volume, ambivalence, cognitive skills, cognitive effort, the spatial orientation of the names on the ballot, and the handedness of the voter, the present study adds new findings to the order-effects literature and encourages future study of the mechanisms and moderators at work in order effects generally. 


\section{ACKNOWLEDGMENTS}

The authors wish to thank Kinesis Survey Technologies for the use of their Internet questionnaire administration software, Luth Research for providing the sample, David Yeager for his assistance, and Josh Pasek for his advice. And the authors thank Herbert Clark for bringing us together as a team. Correspondence concerning this article should be addressed to Jon Krosnick, McClatchy Hall, Stanford University, Bldg. 120, 450 Serra Mall, Stanford, CA 94305-2050. E-mail: krosnick@ stanford.edu

\section{REFERENCES}

Anderson, N. H., \& Hubert, S. (1963). Effects of concomitant verbal recall on order effects in personality impression formation. Journal of Verbal Learning and Verbal Behavior, 2, 379-391.

Alvarez, R. M., Sinclair, B., \& Hasen, R. L. (2006). How much is enough? The "ballot order effect" and the use of social science research in election law disputes. Election Law Journal, 5, 40-56.

Angrist, J., \& Pischke, J. (2009). Mostly harmless econometrics: An empiricist's companion. Princeton, NJ: Princeton University Press.

Asch, S. E. (1946). Forming impressions of personality. Journal of Abnormal and Social Psychology, 41, 1230-1240.

Atwell, C. R., \& Wells, F. L. (1937). Wide range multiple choice vocabulary tests. Journal of Applied Psychology, 21, 550-555.

Banducci, S. A., Karp, J. A., Thrasher, M., \& Rallings, C. (2008). Ballot photographs as cues in low-information elections. Political Psychology, 29, 903-917.

Basinger, S. J., \& Lavine, H. (2005). Ambivalence, information, and electoral choice. American Political Science Review, 99 , $169-184$.

Berger, J. (2011). Does presentation order impact choice after delay? Manuscript under review. http:// marketing.wharton.upenn.edu/documents/research/Citations.pdf

Bruine de Bruin, W. (2005). Save the last dance for me: Unwanted serial position effects in jury evaluations. Acta Psychologica, 118, 245-260.

Brunyé, T., Gardony, A., Mahoney, C. R., \& Taylor, H. A. (2012). Body-specific representations of spatial location. Cognition, 23, 229-239.

Cacioppo, J. T., \& Petty, R. E. (1982). The need for cognition. Journal of Personality and Social Psychology, 42, $116-131$.

Cacioppo, J. T., Gardner, W., \& Berntson, G. G. (1997). Beyond bipolar conceptualizations and measures: The case of attitudes and evaluative space. Personality and Social Psychology Review, 1, 3-25.

Casasanto, D. (2009). Embodiment of abstract concepts: Good and bad in right- and left-handers. Journal of Experimental Psychology, 138, 351-367.

Casasanto, D. (2011). Different bodies, different minds: The body-specificity of language and thought. Current Directions in Psychological Science, 20, 378-383.

Casasanto, D., \& Chrysikou, E. G. (2011). When Left is "Right": Motor fluency shapes abstract concepts. Psychological Science, 22, 419-422.

Casasanto, D., \& Jasmin, K. (2010). Good and bad in the hands of politicians: Spontaneous gestures during positive and negative speech. PLoS ONE, 5(7), e11805.

Ceci, S. J. (1996). General intelligence and life success: An introduction to the special theme. Psychology, Public Policy, and Law, 2, 403-417.

Christenfeld, N. (1995). Choices from identical options. Psychological Science, 6, 50-55.

Clark, E. L. (1956). General response pattern to five-choice items. Journal of Educational Psychology, 47, $110-117$.

Coney, K. A. (1977). Order-bias: The special case of letter preference. Public Opinion Quarterly, 41, 385-388.

Dean, M. L. (1980). Presentation order effects in product taste tests. Journal of Psychology: Interdisciplinary and Applied, $105,107-110$

DeBell, M., \& Krosnick, J. (2009). Computing weights for American National Election Study Survey Data, ANES Technical Report Series (No. nes012427). Ann Arbor, MI: American National Election Studies. Retrieved from http:// www.electionstudies.org/resources/papers/nes012427.pdf

de la Vega, I., de Filippis, M., Lachmair, M., Dudschig, C., \& Kaup, B. (2012). Emotional valence and physical space: limits of interaction. Journal of Experimental Psychology: Human Perception and Performance, 38, 375-385. 
Dillman, D., Smyth, J., \& Christian, L. (2009). Internet, mail, and mixed-mode surveys: The tailored design method. Hoboken, NJ: John Wiley \& Sons.

Fazio, R. H., Powell, M. C., \& Williams, C. J. (1989). The role of attitude accessibility in the attitude-to-behavior process. Journal of Consumer Research, 16, 280-288.

Forgas, J. P. (2011). Can negative affect eliminate the power of first impressions? Affective influences on primacy and recency effects in impression formation. Journal of Experimental Social Psychology, 47, 425-429.

Freedman, D. A. (2008). Randomization does not justify logistic regression. Statistical Science, 23, 237-249.

Glenn, N. D., \& Grimes, M. (1968). Aging, voting and political interest. American Sociological Review, 33, $563-575$.

Haladyna, T., Downing, S., \& Rodriguez, M. (2002). A review of multiple-choice item-writing guidelines for classroom assessment. Applied Measurement in Education, 15, 309-334.

Haugtvedt, C. P., \& Wegener, D. T. (1994). Message order effects in persuasion: An attitude strength perspective. Journal of Consumer Research, 21, 205-218.

Hovland, C. I., Campbell, E. H., \& Brock, T. C. (1957). The effects of "commitment" on opinion change following communication. In C. I. Hovland et al. (Eds.), The order of presentation in persuasion (pp. 23-32). New Haven, CT: Yale University Press.

Ho, D. E., \& Imai, K. (2006). Randomization inference with natural experiments: An analysis of ballot effects in the 2003 California recall election. Journal of the American Statistical Association, 101, 888-900.

Ho, D. E., \& Imai, K. (2008). Estimating causal effects of ballot order from a randomized natural experiment: The California alphabet lottery, 1978-2002. Public Opinion Quarterly, 72, 216-240.

Holbrook, A. L., \& Krosnick, J. A. (2005). Meta-psychological versus operative measures of ambivalence. In S. C. Criag \& M. D. Martinez (Eds.), Ambivalence and the structure of public opinion (pp. 73-103). New York: Palgrave Macmillan.

Jones, E. E., \& Goethals, G. R. (1972). Order effects in impression formation: Attribution context and the nature of the entity. In E. E. Jones, D. E. Kanouse, H. H. Kelley, R. E. Nisbett, S. Valins, \& B. Weiner (Eds.), Attribution: Perceiving the causes of behavior (pp. 27-46). Morristown, NJ: General Learning Press.

King, A., \& Leigh, A. (2009). Are ballot order effects heterogeneous? Social Science Quarterly, 90, 71-87.

Koppell, J. G., \& Steen, J. A. (2004). The effects of ballot position on election outcomes. Journal of Politics, 66, $267-281$.

Krosnick, J. A., \& Alwin, D. F. (1987). An evaluation of a cognitive theory of response order effects in survey measurement. Public Opinion Quarterly, 51, 201-219.

Krosnick, J. A., Miller, J. M., \& Tichy, M. P. (2004). An unrecognized need for ballot reform. In A. Crigler, M. Just, \& E. McCaffery (Eds.), Rethinking the Vote (pp. 51-74). New York, NY: Oxford University Press.

Lavine, H. (2001). The electoral consequences of ambivalence toward presidential candidates. American Journal of Political Science, 45, 915-929.

Maass, A., Pagani, D., \& Berta, E. (2007). How beautiful is the goal and how violent is the fist fight? Spatial bias in the interpretation of human behavior. Social Cognition, 25, 833-852.

Mantonakis, A., Rodero, P., Lesschaeve, I., \& Hastie, R. (2009). Order in choice: Effects of serial position on preferences. Psychological Science, 20, 1309-1312.

Meier, B. P., \& Robinson, M. D. (2004). Why the sunny side is up: Associations between affect and vertical position. Psychological Science, 15, 243-247.

Miller, J. M., \& Krosnick, J. A. (1998). The impact of candidate name order on election outcomes. Public Opinion Quarterly, 62, 291-330.

Mogilner, C., Shiv, B., \& Iyengar, S. S. (2013). Eternal quest for the best: Sequential (vs. simultaneous) option presentation undermines choice commitment. Journal of Consumer Research, 39, 1300-1312.

Pasek, J. (2010). ANESrake: ANES Raking Implementation. Comprehensive R Archive Network. Version 0.4 [July 12, 2010$].$ Retrieved from http://cran.r-project.org/web/packages/anesrake/index.html

Pasek, J., DeBell, M., \& Krosnick, J. A. (2010, May). Toward a standardization of survey weights: The American National Election Studies weighting system. Paper presented at the 65th annual conference of AAPOR, Chicago.

Stepper, S., \& Strack, F. (1993). Proprioceptive determinants of emotional and nonemotional feelings. Journal of Personality and Social Psychology, 64, 211-220.

Thompson, M., Zanna, M., \& Griffin, D. (1995). Let's not be indifferent about (attitudinal) ambivalence. In R. Petty \& J. Krosnick (Eds.), Attitude strength: Antecedents and consequences (pp. 361-386). Mahwah, NJ: Lawrence Erlbaum.

Tourangeau, R., Couper, M. P., \& Conrad, F. G. (2013). "Up means good": The effect of screen position on evaluative ratings in web surveys. Public Opinion Quarterly, 77, 69-88.

U. S. Census Bureau. (2009, March). Current population survey: Annual social and economic supplement. Retrieved from http://www.census.gov/hhes/www/cpstc/cps_table_creator.html 
U. S. Census Bureau. (2010, April). Genealogy data: Frequently occurring surnames from Census 1990. Retrieved from https://www.census.gov/genealogy/www/data/1990surnames/names_files.html

Webster, D. M., Richter, L., \& Kruglanski, A. W. (1996). On leaping to conclusions when feeling tired: Mental fatigue effects on impressional primacy. Journal of Experimental Social Psychology, 32, 181-195.

\section{Appendix}

Wordings and Codings of Demographic Questions

\begin{tabular}{|c|c|c|}
\hline Variable & Question Wording & Coding \\
\hline Age & In what month and year were you born? & 2010-Year of birth \\
\hline Race & $\begin{array}{l}\text { Below are five race categories. Please choose one or more races } \\
\text { that you consider yourself to be. White; Black or African } \\
\text { American; American Indian or Alaskan Native; Asian; Native } \\
\text { Hawaiian or other Pacific Islander; Other }\end{array}$ & $\begin{array}{l}\text { African American }=1 \text {; Other } \\
\quad \text { race }=0\end{array}$ \\
\hline Hispanic & Are you Spanish, Hispanic, or Latino? & $\begin{array}{l}\text { Hispanic }=1 \\
\text { Non-Hispanic }=0\end{array}$ \\
\hline Gender & Are you male or female? & Female $=1 ;$ Male $=0$ \\
\hline Income & $\begin{array}{l}\text { Which category below represents the total combined income of all } \\
\text { members of your FAMILY during the past } 12 \text { months? This } \\
\text { includes money from jobs, net income from business, farm or } \\
\text { rent, pensions, dividends, interest, social security payments, and } \\
\text { any other money income received by members of your } \\
\text { FAMILY who are FIFTEEN (15) years of age or older. Less } \\
\text { than } \$ 5,000 ; \$ 5,000 \text { to } 7,499 ; \$ 7,500 \text { to } 9,999 ; \$ 10,000 \text { to } \\
12,499 ; \$ 12,500 \text { to } 14,999 ; \$ 15,000 \text { to } 19,999 ; \$ 20,000 \text { to } \\
24,999 ; \$ 25,000 \text { to } 29,999 ; \$ 30,000 \text { to } 34,999 ; \$ 35,000 \text { to } \\
39,999 ; \$ 40,000 \text { to } 49,999 ; \$ 50,000 \text { to } 59,999 ; \$ 60,000 \text { to } \\
74,999 ; \$ 75,000 \text { to } 99,999 ; \$ 100,000 \text { to } 149,999 ; \$ 150,000 \text { or } \\
\text { more }\end{array}$ & $\begin{array}{l}\text { Less than } \$ 20,000=1 \\
\$ 20,000-\$ 34,999=2 \\
\$ 35,000-\$ 49,999=3 \\
\$ 50,000-\$ 74,999=4 \\
\$ 75,000-\$ 99,999=5 \\
\text { More than } \$ 100,000=6\end{array}$ \\
\hline Education & $\begin{array}{l}\text { What is the highest level of school you have completed or the } \\
\text { highest degree you have received? } 1^{\text {st }}, 2^{\text {nd }}, 3^{\text {rd }}, \text { or } 4^{\text {th }} \text { grade; } 5^{\text {th }} \\
\text { or } 6^{\text {th }} \text { grade; } 7^{\text {th }} \text { or } 8^{\text {th }} \text { grade; } 9^{\text {th }} \text { grade; } 10^{\text {th }} \text { grade; } 11^{\text {th }} \text { grade; } \\
12^{\text {th }} \text { grade no diploma; High school graduate-Diploma or } \\
\text { equivalent; Some college but no degree; Associate } \\
\text { degree-Occupational/ vocational; Associate } \\
\text { degree-Academic program; Bachelor's degree; Master's } \\
\text { degree; Professional school degree; Doctorate degree }\end{array}$ & $\begin{array}{l}\text { Low education = All categories } \\
\text { up to "High school } \\
\text { graduate-Diploma or } \\
\text { equivalent", inclusive; High } \\
\text { education = All categories above } \\
\text { "High school graduate-Diploma } \\
\text { or equivalent" }\end{array}$ \\
\hline
\end{tabular}

